\title{
Commitment Decisions: Is the Sky the Limit? Commentary to Judgment of the General Court (Eighth Chamber) of 15 September 2016, T-76/14, Morningstar, Inc. v European Commission
}

\author{
Rita Leandro Vasconcelos ${ }^{*}$
}

\begin{abstract}
In its judgment of 15 September $2016,{ }^{1}$ the General Court ruled on whether the commitments offered by Thompson Reuters to the European Commission during an investigation of a possible abuse of dominant position were sufficient to address the competition concerns identified by the Commission.

This is only the second time the Court of Justice of the European Union ${ }^{2}$ ruled on Commission decisions rendering binding the commitments offered by an undertaking under Article 9 of Regulation 1/2003. ${ }^{3}$ With regard to standing, the General Court ruled the appeal lodged by a competitor admissible. As for substance, the General Court generally confirmed the previous case law. It ruled on the wide discretion of the Commission when adopting commitment decisions as long as the commitments meet the competition concerns identified by the institution, the different proportionality standard in Article 9 decisions as compared to Article 7 Regulation 1/2003 decisions (formal decision finding an infringement), and the limited scope of judicial review of the Court of Justice of the European Union in these appeals.
\end{abstract}

KEYWORDS: Commitment decisions; judicial review; proportionality.

\footnotetext{
${ }^{*} \mathrm{PhD}$ candidate at the Oporto Law School of the Universidade Católica Portuguesa, 4169-005 Porto, Portugal; Lawyer atCuatrecasas. rvasconcelos@cuatrecasas.com.

${ }^{1}$ Judgment of 15 September 2016, Morningstar, Inc. v European Commission, T-76/14, EU:T:2016:481.

${ }^{2}$ Comprising the Court of Justice, the General Court and specialized courts.

${ }^{3}$ Council Regulation (EC) No 1/2003 of 16 December 2002 on the implementation of the rules on competition laid down in Articles 81 and 82 of the Treaty (Official Journal L 1, 4 January 2003, $1-25)$.
} 


\section{The facts, the appeal and the judgment}

The Commission opened proceedings against Thomson Reuters Corporation and companies under its direct or indirect control, including Reuters Limited (Thomson Reuters), on 30 October 2009 and found in its preliminary assessment issued on 19 September 2011 that the undertaking might have abused an alleged dominant position in the worldwide market for consolidated realtime datafeeds. According to the Commission, Thomson Reuters may have abused its dominant position by imposing certain restrictions regarding the use of its alphanumerical codes, the Reuters Instrument Codes (RICs).

RICs are used to identify securities and their trading locations from Thomson Reuters' datafeeds. The Commission claimed that Thomson Reuters allegedly prevented customers from using RICs to retrieve data from the consolidated real-time datafeeds of other providers and prevented third parties and other providers from developing and maintaining mapping tables incorporating RICs in order for its customers' systems to interoperate with the consolidated real-time datafeeds of other providers. In the Commission's view, Thomson Reuters' practices allegedly created substantial barriers to switching data feed providers, which could constitute an abuse of dominant position under Article 102 of the Treaty on the Functioning of the European Union (TFEU) and Article 54 of the Agreement on the European Economic Area (EEA).

During the procedure, Thomson Reuters offered three sets of commitment proposals to address the Commission's competition concerns. Following market testing, the Commission accepted the third and final set of commitments offered by Thomson Reuters. The undertaking committed to offer its customers an extended licence agreement (ERL) enabling them to use RICs to retrieve real-time data from competing providers, to provide a separate supplementary licence (TPDL) allowing third-party developers to develop, maintain and update mapping tables, and to enter into agreements with other consolidated real-time datafeed providers for the development of such mapping tables. Being of the view that these commitments would allow Thomson Reuters' customers to switch providers and were therefore sufficient to meet the competition concerns expressed in the preliminary assessment, the Commission accepted and rendered the commitments legally binding by decision of 20 December $2012 .{ }^{4}$

\footnotetext{
${ }^{4}$ Commission Decision of 20 December 2012, Case COMP/D2/39.654 - Reuters Instrument Codes (RICs) (Official Journal C 326, 12 November 2013, 4).
} 
On 4 February 2014, Morningstar, Inc. (Morningstar), a competing consolidated real-time datafeed provider, brought an appeal against the Commission's decision. It argued that the Commission had committed a manifest error of assessment by accepting commitments that in Morningstar's view did not meet the competition concerns shown in the Commission's preliminary assessment, which corresponded to the possibility of customers to switch providers. The applicant added that for that reason the Commission had acted ultra vires, since it had exceeded the powers granted to it by Regulation 1/2003 and breached the principle of proportionality. In Morningstar's opinion, the commitments should have included licences for competing providers in order for them to develop the relevant tools and effectively allow the customers to switch providers. Lastly, Morningstar stated that the Commission had infringed its duty to state reasons.

The General Court dismissed Morningstar's appeal entirely, confirming the limited scope of judicial review of the Court of Justice of the European Union in these appeals.

In the subsequent points we will discuss the pleas and the analysis of the General Court.

\section{Locus standi}

The first issue to be addressed by the General Court was Morningstar's standing to bring this appeal before the Court. The General Court concluded that Morningstar possessed such standing and thus the action was admissible.

The General Court started by stating that Article 263 TFEU "allows a person other than the person to whom the act is addressed to institute proceedings for annulment of that act if that act is of individual and direct concern to him" (paragraph 29 of Morningstar judgment). It then built on previous case law from the Court of Justice to confirm that "the question of whether an applicant has locus standi is to be assessed by reference to the effects that the contested act has on its legal situation in so far as that applicant is, first, directly concerned by the contested act, in that the direct concern requires that the measure at issue must directly affect the legal situation and that the act must leave no discretion to the addressees of that measure who are entrusted with the task of implementing it, such implementation being purely automatic and resulting from the EU rules alone without the application of other 
intermediate rules"5 and "second, individually concerned by that act in that it affects the applicant by reason of certain attributes particular to him or by reason of circumstances in which he is differentiated from all other persons and by virtue of those factors the decision distinguishes him individually just as in the case of the person addressed"6 (paragraph 30 of Morningstar judgment).

The General Court considered that Morningstar was directly and individually concerned by the decision due to a number of factors.

With regard to the criterion of being directly affected by the contested measure, the General Court concluded that Morningstar was directly affected as the Commission, after deciding that Thomson Reuters' behaviour hindered the ability of its customers to switch providers thus reducing the competitors' ability to compete made Thomson Reuter's commitments binding. Those commitments, which aim at facilitating the switch of providers, explicitly exclude competitors from being eligible to enter into either an extended license agreement or a third-party developer licence agreement (paragraph 31 of the judgment). Therefore, the Commission's decision directly affects Morningstar.

The criterion of being individually concerned by the contested decision merited more elaboration from the General Court, which eventually concluded for its applicability. First, Morningstar participated actively in the procedure both at its own initiative and at the request of the Commission. Notably, it held meetings and telephone conversations with the institution, responded to formal requests for information, provided observations in relation to the commitments proposed by Thomson Reuters (paragraphs 32 and 34 of the judgment) and, according to the General Court, "even though the applicant's name does not explicitly feature in the contested decision, it is clear from the administrative procedure which resulted in that decision that the Commission took into account the observations made by the applicant" (paragraph 33 of the Morningstar judgment). The General Court took into account the Court of Justice's case law on participation in the procedure in the field of competition law. ${ }^{7}$

\footnotetext{
${ }^{5}$ Judgments of 5 May 1998, Glencore Grain v Commission, C404/96 P, EU:C:1998:196, paragraph 42, and of 24 March 1994, Air France v Commission, T3/93, EU:T:1994:36, paragraph 80.

${ }^{6}$ Judgment of 15 July 1963, Plaumann $v$ Commission, 25/62, EU:C:1963:17, paragraph 107.

${ }^{7}$ Judgments of 28 January 1986, Cofaz and others $v$ Commission, 169/84, EU:C:1986:42, paragraphs 24 and 25; of 31 March 1998, France and others $v$ Commission ("Kali und Salz"), C-68/94 and C-30/95, EU:C:1998:148, paragraphs 54 to 56; and of 3 April 2003, Babyliss $v$ Commission, T-114/02, EU:T:2003:100, paragraph 95.
} 
Second, the General Court considered that it was not sufficient to participate in the procedure to be given standing to bring an action for annulment. "Other specific circumstances" must be present and those specific circumstances were, in Morningstar's case, the manner in which the applicant's position on the market was affected (paragraph 35 of the judgment). Morningstar was a competitor of Thomson Reuters in the market for consolidated real-time datafeed, a concentrated market where Thompson Reuters had a dominant position. In such a market, the allegedly restrictive measures identified by the Commission in its preliminary assessment could have a significant effect on Morningstar's business.

\section{The substantive pleas and the powers of the Court}

Morningstar relied on four pleas to the General Court. First, it held that the Commission had committed a manifest error of assessment by accepting commitments, which did not meet the competition concerns about which it had notified Thomson Reuters in its preliminary assessment. Second, it argued that the Commission had breached Article 9 (1) of Regulation $1 / 2003$ by accepting commitments which were not capable of addressing the competition concerns, acting beyond the scope of the powers available to it under that article and, therefore, ultra vires. Third, Morningstar pled that the Commission had breached the principle of proportionality. Finally, in Morningstar's view, the Commission had infringed the obligation to state reasons in so far that it had failed to explain how the final commitments met the competition concerns identified.

The pleas were analysed as follows. First, the General Court recalled the powers of the Court when reviewing the Commission's decisions regarding accepting or rejecting commitments. Then, the General Court analysed the pleas of manifest error of assessment and subsequently the Commission acting beyond the scope of its powers, considering that in substance the rejection of the first plea resulted in the rejection of the second. The General Court went on to analyse the plea on the breach of the principle of proportionality, also rejecting it, and in the end rejected the fourth plea on the omission of reasons for its decision. ${ }^{8}$

\footnotetext{
${ }^{8}$ The General Court rejected the argument based on previous case law from the Court of Justice (judgments of 2 April 1998, Commission v Sytraval and Brink's France, C-367/95 P, EU:C:1998:154, paragraph 63; and of 10 July 2008, Bertelsmann and Sony Corporation of America $v$ Impala, C-413/06 P, EU:C:2008:392, paragraphs 166 and 178). It stated that although the Commission is required to provide reasons for the decision which it adopts, it is not obliged to explain why it
} 


\subsection{The limited power of judicial review of the EU Courts in the context of Article 9 decisions}

The General Court started by recalling the principles of its powers of review of Commission's decisions rendering binding the commitments offered by the undertakings at stake where they address the competition concerns expressed by the Commission in its preliminary assessment according to Article 9 of Regulation 1/2003.

Building on previous case law, the General Court stated that the Commission enjoys a wide margin of discretion as regards the acceptance or rejection of commitments (paragraph 40 of the Morningstar judgment). The Commission also enjoys a considerable degree of discretion when it is called upon to carry out a complex economic and forward-looking analysis involving numerous economic factors in order to assess the adequacy and appropriateness of the commitments offered by the undertaking concerned to meet the concerns identified in the Commission's preliminary assessment, and the EU Courts cannot substitute their own economic assessment for that of the Commission. Therefore, the EU Courts only enjoy a restricted power of judicial review regarding such complex economic situation (paragraph 41 of the Morningstar judgment).

However, this restricted power of judicial review does not mean that the Courts do not enjoy such power at all. Indeed, the EU Courts must review the Commission's interpretation of information of an economic nature, ${ }^{9}$ establish whether the evidence relied on by the Commission is "factually accurate, reliable and consistent", whether that evidence contains "all the information which must be taken into account in order to assess a complex situation", and if it is able to substantiate the conclusions drawn by the institution (paragraph 42 of the Morningstar judgment). ${ }^{10}$

After the General Court's conclusions on its powers of judicial review regarding Commission's decisions in complex economic situations and in the context of Article 9 Regulation 1/2003 decisions, the General Court went on to evaluate its powers of review in the case at stake.

\footnotetext{
refrained from adopting a different decision (paragraph 101 of the judgment). We are not going to explore this line of arguments in the present commentary, but rather focus on the judicial review of Article 9 of Regulation 1/2003.

${ }^{9}$ Judgments of 15 February 2005, Commission v Tetra Laval, C-12/03 P, EU:C:2005:87, paragraph 39; of 10 July 2008, Bertelsmann and Sonny Corporation of America v Impala, C-413/06 P, EU:C:2008:392, paragraph 145.

${ }^{10}$ Judgment of 11 September 2014, CB v Commission, C-67/13 P, EU:C:2014:2204, paragraph 46.
} 
The applicant pleaded that the Commission had committed a manifest error of assessment by accepting commitments which did not address the competition concerns about which it had notified Thomson Reuters in its preliminary assessment and, for that reason, it had exceeded the scope of the powers attributed by Article 9 Regulation 1/2003.

In the applicant's view, the fact that the definition of "eligible customer" and "third-party developers" for the purpose of the licences excluded competing consolidated real-time datafeed providers from being licensees hindered the possibility of customers switching provider and thus did not enable the commitments to meet the concerns expressed by the Commission in its preliminary assessment. Morningstar believed that the commitments were not effective because they did not enable competing providers to offer a fully integrated competing service and third parties were not likely to develop competing mapping tables. The burden and cost of switching providers would fall upon Thomson Reuters' customers, due to the need to modify their systems and adapt them to use a third party's mapping table. Further, according to Morningstar, third-party mapping tables and conversion tools were less reliable and ineffective due to the impossibility of exchanging information regarding RICs and the fact that chain RICs (a method of accessing a group of instruments through a single identifier, used by banks and financial institutions) were excluded from the licences. The applicant based its pleas on the fact that, until that time, none of Thomson Reuters' customers had used a competing consolidated real-time datafeed provider.

The Commission, though, stood by the position that the commitments were sufficient to meet the competition concerns identified in the preliminary assessment. Notably, a competitor could establish a partnership with a third-party developer to offer Thomson Reuters' customers a personalized and fully integrated service for switching providers; switching costs were inevitable because the IT architecture of each customer is usually specific to it, but given that Thomson Reuters' major customers were global financial institutions with the means and the expertise to switch providers, they would switch if it were convenient. The Commission also considered that there were no reasons to believe that mapping tables developed by third-party developers would be unreliable or slower. Finally, the Commission considered that there had been little time for customers to switch providers given that it is a long and complex process. ${ }^{11}$

\footnotetext{
${ }^{11}$ The Commission also rejected the argument regarding chain RICs, stating that it had only been introduced in the reply and was not based upon matters of law or fact, which had arisen during the administrative procedure and the procedure before the General Court. The General Court,
} 
The General Court recalled the discretion enjoyed by the Commission when assessing the appropriateness of the commitments offered by the undertakings concerned, and stated that its role is limited to establishing that the Commission did not commit a manifest error of assessment. In particular, the role of the Court is to "determine whether a balance has been struck between the concerns raised by the Commission in its preliminary assessment and the commitments proposed" by the undertaking, which must be able to adequately address those concerns (paragraph 56 of the Morningstar judgment).

The General Court stressed that "the review of the lawfulness of the decision making those commitments binding must be assessed in the light of the Commission's concerns and not of the demands put forward by competitors in relation to the content of those commitments" (paragraph 57 of the Morningstar judgment).

In this regard, it is first necessary to determine the objective of the commitments - which in the Morningstar case was to make it easier for customers to switch providers - and then whether those commitments are able to adequately address those concerns (paragraph 58 of the Morningstar judgment).

The General Court considered that the Commission had not committed a manifest error of assessment because the commitments were able to resolve the Commission's concerns (paragraph 72 of the judgment). The General Court took the view that those commitments focused on the opportunities available for customers to switch providers, either on their own or with a third-party developer, rather than on the opportunities for the competitors to present themselves as an alternative for those customers (paragraphs 62 and 63 of the judgment). The objective of those commitments was not to eliminate all switching costs that arise from a change in IT architecture, but rather to facilitate switching within reasonable costs (paragraphs 67 and 68 of the judgment).

\subsection{The nature of commitment decisions}

The General Court stressed that the purpose of Article 9 of Regulation $1 / 2003$ was to "ensure that the competition rules in force in the European Union are applied effectively, by means of the adoption of decisions

however, considered that this plea was an amplification of the other ones and held the argument admissible (paragraph 55 of the Morningstar judgment). 
making commitments proposed by the parties and considered appropriate by the Commission binding, in order to provide a more rapid solution to the competition problems identified by the Commission, instead of proceeding by making a formal finding of an infringement. More particularly, Article 9 of that regulation is based on considerations of procedural economy and enables undertakings to participate fully in the procedure by putting forward the solutions which appear to them to be the most appropriate and capable of addressing the Commission's concerns" (paragraph 39 of the Morningstar judgment). ${ }^{12}$

In this regard, the analysis carried out by the Commission was necessarily forward-looking (paragraph 41 of the judgment) and its assessment as regards the commitments offered by the undertakings concerned was a prospective one, similar to that of merger control proceedings (paragraph 73 of the judgment). For this reason, the fact that no customer had switched suppliers was not a reason to annul the decision. In fact, it is not for the Court to determine whether the commitments have in the meanwhile produced an actual effect on the market, but whether the commitments were sufficient to remove the competition concerns when the decision was adopted. If, the General Court continued, the customers did not want to switch providers that does not mean that the remedy failed.

The General Court thus acknowledged the difficulty for the Commission to craft remedies for the future which, on the one hand, are effective in restoring competition and, on the other, do not jeopardise the position of the undertaking at stake, bearing in mind that Article 102 TFEU does not prohibit dominant position as such.

\subsection{The principle of proportionality in the context of Article 9 decisions}

Morningstar argued that the Commission had infringed the principle of proportionality by accepting inappropriate commitments that did not take account of third-party interests.

The General Court, in line with the arguments of the Commission, rejected the plea. As a rule, the measures adopted by EU institutions must be bound by the principle of proportionality and must not exceed what is appropriate and necessary to attain the objective pursued by such measure. When facing more than one appropriate measure, the institution must

${ }^{12}$ See also judgment of 29 June 2010, Commission v Alrosa, C-441/07 P, EU:C:2010:377, paragraph 35. 
choose the least onerous one (paragraphs 84 and 85 of the Morningstar judgment). ${ }^{13}$

In the context of Article 9 decisions, the principle of proportionality is respected when the Commission verifies, first, that the commitments offered by the undertakings meet the concerns identified in the preliminary assessment and, second, that the undertakings have not offered less onerous commitments that are also adequate to solve the competition concerns (paragraph 86 of the Morningstar judgment). The General Court went on stating that "if undertakings offer commitments on the basis of Article 9 of Regulation 1/2003 which go beyond that which the Commission itself could have imposed on them in a decision that it adopted in accordance with Article 7 of that regulation following a thorough review, the Commission can accept those commitments and make them binding. However, it is not entitled to require them under Article 9 of Regulation 1/2003" (paragraph 89 of the judgment).

The General Court clearly built on Alrosa judgment, by stating that the Commission can accept more onerous commitments in Article 9 decisions than the ones that it may require under Article 7 decisions. The Morningstar case is, however, different, as the General Court recognizes in the last sentence of paragraph 89 of the judgment. In the Alrosa case, the applicant was trying to annul the Commission's decision because it considered that the commitments went beyond what was necessary to meet the Commission's preliminary concerns. ${ }^{14}$ The Court of Justice took the view that, when applying Article 9 of Regulation 1/2003, the Commission can accept commitments offered by the undertakings concerned even though they exceed what is necessary to address the competition concerns identified by the institution in its preliminary assessment. In the Morningstar case the applicant did not argue that the commitments exceeded what was necessary to address the Commission's concerns, as in Alrosa, but, on the contrary, that they were not sufficient to meet them. As regards the issue of sufficiency the General Court stated that "the fact that other commitments could also have been accepted, or might even have been more favourable to

\footnotetext{
${ }^{13}$ See also judgments of 17 May 1984, Denkavit Nederland, 15/83, EU:C:1984:183, paragraph 25; of 11 July 1989, Schräder HS Kraftfutter, 265/87, EU:C:1989:303, paragraph 21; and of 29 June 2010, Commission v Alrosa, C-441/07 P, EU:C:2010:377, paragraph 36.

${ }^{14}$ Alrosa judgment, paragraphs 56-58.
} 
competition" was not a valid ground for annulment of the decision (paragraph 59 of the Morningstar judgment). ${ }^{15}$

\section{Commentary}

Article 9 of Regulation 1/2003 allows the Commission to close proceedings brought under Articles 101 and 102 TFEU by rendering commitments binding on the undertakings concerned. Those undertakings offer commitments in order to meet the competition concerns identified by the Commission in its preliminary assessment and thus avoid the adoption of a formal finding of an infringement decision under Article 7 of Regulation 1/2003. Commitment decisions should find that there are no longer grounds for action by the Commission without concluding whether there has been or still is an infringement. ${ }^{16}$

The European Commission has shown in the last years an increasing willingness to end procedures by making binding commitments offered by the undertakings concerned within the scope of Article 9 of Regulation $1 / 2003 .{ }^{17}$ Given that there is no finding of an infringement and thus no need to develop a clear theory of harm, the use of this procedure may end up in swifter outcomes ${ }^{18}$ and the burden of proof of the Commission is lower. In addition, as the proportionality requirements are subject to a lower standard, the Commission may accept and make binding commitments comprising broader remedies than it could have imposed in an Article 7 procedure. ${ }^{19}$ This has led to concerns that the Commission may use Article 9 Regulation 1/2003 to pursue regulatory goals ${ }^{20}$ or take on excessive intervention. ${ }^{21}$

\footnotetext{
${ }^{15}$ This argument was, in fact, introduced under the first plea. However, we believe that it is more related to the issue of proportionality and will analyse it in this section.

${ }^{16}$ Recital 13 of Regulation 1/2003.

${ }^{17}$ Yves Botteman and Agapi Patsa, "Towards a More Sustainable Use of Commitment Decisions in Article 102 Cases", Journal of Antitrust Enforcement 1, no. 2 (2013), 352.

${ }^{18}$ Richard Whish and David Bailey, Competition Law. $8^{\text {th }}$ ed. (Oxford, Oxford University Press, 2015), 268.

${ }^{19}$ Frederic Jenny, "Worst Decision of the EU Court of Justice: The Alrosa Judgment in Context and the Future of Commitment Decisions", Fordham International Law Journal 38 (2015), 726.

${ }^{20}$ Heike Schweitzer, "Commitment Decisions under Art. 9 of Regulation 1/2003: The Developing EC Practice and Case Law”, EUI Working Papers LAW 2008/22 (2008) http://cadmus.eui.eu/bitstream/handle/1814/9449/LAW_2008_22.pdf?sequence=1\&isAllowed=y, 27.

${ }^{21}$ John Temple Lang, "Commitment Decisions and Settlements with Antitrust Authorities and Private Parties under European Competition Law", in Annual Proceedings of the 2005 Fordham Corporate Law Institute, ed. Barry Hawk (Huntington: Juris Publishing, 2006), 318.
} 
The undertakings concerned can, nevertheless, derive some benefits out of this procedure. Not only do they avoid a fine, but they also protect their reputation and may have more legal certainty, given that in Article 9 procedures the undertakings are involved in the design of the measure. ${ }^{22}$

Notwithstanding, the overuse of Article 9 decisions by the European Commission may have some negative effects, notably the lack of decisional practice and case law of the EU Courts. ${ }^{23}$ In fact, in Article 9 decisions the Commission does not need to build a concrete theory of harm, being enough to present competition concerns. ${ }^{24}$ In addition, given the voluntary nature of the process and the involvement of the undertakings concerned, the grounds and the willingness of the undertakings to appeal commitment decisions are more limited, ${ }^{25}$ thus lessening the opportunities for the EU Courts to review such decisions. This hinders the development of precedents, which is especially problematic in novel cases. ${ }^{26}$ This was part of the concerns that some authors raised against the Commission's initial position of accepting commitments in the Google case. ${ }^{27}$ At the time of writing, the Commission rejected the commitment packages offered by Google and adopted an Article 7 decision. ${ }^{28}$

Morningstar judgment was one of the rare opportunities ${ }^{29}$ for the General Court to take position on the boundaries of the Commission's

\footnotetext{
${ }^{22}$ Rita Leandro Vasconcelos, "Remedies and Article 102 TFEU: Recent Public Enforcement Experience", in Competition Law Challenges in the Next Decade, ed. Sofia Oliveira Pais (Brussels: P.I.E. Peter Lang, 2016), 190.

${ }^{23}$ Alison Jones and Brenda Sufrin, EU Competition Law: Text, Cases and Materials (Oxford: Oxford University Press, 2016), 953.

${ }^{24}$ Commitment decisions are also typically shorter. Ian Forrester, "Creating New Rules or Closing Easy Cases", in European Competition Law Annual 2008, ed. Claus-Dieter Ehlermann and Mel Marquis (Oxford: Hart Publishing, 2009), 637.

${ }^{25}$ Frederic Jenny, "Worst Decision of the EU Court of Justice: The Alrosa Judgment in Context and the Future of Commitment Decisions", 723.

${ }^{26}$ Philip Marsden, "The Emperor's Clothes Laid Bare: Commitments Creating the Appearance of Law, while Denying Access to Law", CPI Antitrust Chronicle (October 2013) (1), 5.

${ }^{27}$ Yves Botteman and Agapi Patsa, "Towards a More Sustainable Use of Commitment Decisions in Article 102 Cases", 348. For a discussion on the application of Article 102 TFEU to the Google case and the need for a "transparent and intellectually rigorous" process, see Renato Nazzini, "Google and the (Ever-stretching) Boundaries of Article 102 TFEU”, Journal of European Competition Law \& Practice 6, no. 5 (2015), 301-314.

${ }^{28}$ See European Commission Press release of 27 June 2007.

${ }^{29}$ There was another appeal in 2010 from Hynix of an Article 9 Commission decision in the Case COMP/38.636 - Rambus, where Hynix, a complainant, appealed the Commission's decision considering that it should have opted for a formal finding of an infringement decision under Article 7
} 
discretional powers and on the European Court of Justice's own scope of judicial review, the General Court having confirmed the principles laid down in the Alrosa judgment. The judgment did shed some light on the issues of standing and of which commitments the Commission is bound to accept, thus bringing more legal certainty for the undertakings that wish to propose commitments to the Commission..$^{30}$ Nevertheless, some questions remained unanswered.

As for standing, the General Court clarified the possibilities of appeal by third parties with regard to Alrosa. Morningstar judgment was one of the few cases where a third party challenged a Commission decision accepting commitments. In the first case, Alrosa, ${ }^{31}$ the appellant was not an undertaking concerned for the purpose of that one procedure that regarded De Beer's unilateral practices under Article 102 and gave rise to the commitment's decision. ${ }^{32}$ However, the appellant had been an undertaking concerned in the procedure involving both Alrosa and De Beers under Article 101 TFEU, where both undertakings had offered joint commitments that were rejected by the Commission under its Article 9 powers. Additionally, in the Alrosa judgment, the applicant was very closely affected by the commitments offered by De Beers alone in its Article 102 procedure, which included the unilateral termination of its contractual relationship with Alrosa. This was, thus, a different and somewhat more restrictive case than Morningstar's. ${ }^{33}$ By contrast, Morningstar was a third party to the procedure (although it had been very active in it) and, hence, it is possible to derive more general principles from the Morningstar judgment ${ }^{34}$ since it does clarify the criteria to become an applicant in Article 9 decisions when compared to Alrosa (see section 2 above).

Notwithstanding, in both cases the applicants saw affected their situation in the market. According to settled case law, a contested EU measure that is not addressed to the applicant directly affects the applicant when it

of Regulation 1/2003 (joined cases T-148/10 and T-149/10). The appeal was withdrawn and the cases were removed from the register.

${ }^{30}$ Dieter Paemen, "Morningstarv. Commission: Raising the Threshold for Challenging Commission Commitments Decisions", Journal of European Competition Law \& Practice 8, no. 2 (2017), 101.

${ }^{31}$ Judgment of 29 June 2010, Commission v Alrosa, C-441/07 P, EU:C:2010:377.

${ }^{32}$ Judgment of 29 June 2010, Commission v Alrosa, C-441/07 P, EU:C:2010:377, paragraphs 88 and 89.

${ }^{33}$ Dieter Paemen and Victoria S. Baltrusch, "Morningstar v. Commission: Raising the Threshold for Challenging Commission Commitments Decisions", 100.

${ }^{34}$ Dieter Paemen and Victoria S. Baltrusch, "Morningstar v. Commission: Raising the Threshold for Challenging Commission Commitments Decisions", 100. 
is capable of directly producing effects on the applicant's legal situation. ${ }^{35}$ Applicants are individually concerned when the measure "affects them by reason of certain attributes which are peculiar to them or by reason of circumstances in which they are differentiated from all other persons and by virtue of these factors the decision distinguishes them individually just as in the case of the person addressed" by such measure. ${ }^{36}$ The applicant does not need to stand in a specific position (competitor, customer or supplier) to bring proceedings. ${ }^{37}$ However, it may be more difficult for a party to prove directly and individually affected in order to have interest in bringing an action for annulment when the outcome of the procedure does not have a direct adverse effect on its situation in the market or business activity. For example, the Court of Justice has already denied standing to customers of cartel members to intervene in appeal proceedings on the grounds of being customers affected by high prices and wishing to bring follow-on damages. ${ }^{38}$ The reason lies in the fact that the purpose of the action for annulment is to review the legality of the Commission's deci$\operatorname{sion}^{39}$ and not to award remedies to an injured party.

With regard to the powers of the Commission to accept commitments in Article 9 decisions and its judicial review, the General Court stressed the institution's broad margin of discretion. In order to rule on the manifest error of assessment, the Court had to consider the substance of the commitments against the preliminary concerns identified by the Commission in the contested decision. ${ }^{40}$ What is striking is that while analysing the

\footnotetext{
${ }^{35}$ Koen Lenaerts, Ignace Maselis and Kathleen Gutman, EU Procedural Law (Oxford: Oxford University Press, 2014), 319.

${ }^{36}$ Judgment of 15 July 1963, Plaumann v Commission, 25/62, EU:C:1963:17, 107.

${ }^{37}$ With the same conclusion for merger control cases where third parties want to challenge the Commission's decision with remedies, see Dorte Hoeg, European Merger Remedies: Law and Policy (Oxford and Portland, Oregon: Hart Publishing, 2014), 182. See also judgement of the General Court of 21 March 2002, Shaw and Falla $v$ Commission, T-131/99, EU:T:2002:83, paragraphs 25 to 27.

${ }^{38}$ Orders of the President of the Court of 8 June 2012, Schenker v Air France and Commission, C-589/11 P, EU:C:2012:332, paragraphs 15 and 23; of 8 June 2012, Schenker $v$ Air France-KLM and Commission, C-590/11 P, EU:C:2012:333; Schenker $v$ KLM and Commission, C-596/11 P, EU:C:2012:334; Schenker $v$ Cathay Pacific Commission, C -598/11 P, EU:C:2012:335; Schenker v Lan Airlines ad others, C-600/11 P, EU:C:2012:336; Schenker v Deutsche Lufthansa and Others, C-602/11 P, EU:C:2012:337.

${ }^{39}$ Luis Ortiz Blanco (ed.), EU Competition Procedure. $3^{\text {rd }}$ ed. (Oxford: Oxford University Press, 2013), 674.

${ }^{40}$ Dieter Paemen and Victoria S. Baltrusch, "Morningstar v. Commission: Raising the Threshold for Challenging Commission Commitments Decisions”, 100.
} 
Commission's decision, the General Court focused on the issues that the Commission had identified in its preliminary assessment without questioning them - notwithstanding having recalled the case law of the EU Courts whereby it must determine whether the information on which the decision is based is accurate, consistent and complete, and verify the interpretation of the Commission of that information - and limited its own power of judicial review to whether the commitments accepted by the Commission were able to meet those competition concerns. This shows not only that in Article 9 Regulation 1/2003 decisions the Commission enjoys a very wide margin of discretion and those commitment decisions are subject to a lower intensity of review, ${ }^{41}$ but also that the EU Courts have some deference to the Commission in Article 102 TFEU cases. ${ }^{42}$

The General Court also confirmed that the principle of proportionality in the context of Article 9 decisions is more lenient that in the context of Article 7 decisions, where the Commission is required to choose the less onerous remedy. The difference between Alrosa and Morningstar is that in the former case, the applicant claimed that the commitments were excessive and, in the latter, the applicant claimed that they were not sufficient to remedy the preliminary concerns expressed by the Commission. The General Court clearly stated that in the context of Article 9 decisions, the Commission can accept and make binding commitments that go beyond the ones that the Commission could have imposed on the undertakings concerned. In Morningstar, the General Court thus maintained the Court of Justice's position in Alrosa, which was the object of some criticism, mainly due to a relaxation of proportionality requirements ${ }^{43}$ and concerns

\footnotetext{
${ }^{41}$ Ioannis Lianos, "Competition Law remedies in Europe", Handbook on European Competition Law: Enforcement and Procedure, ed. Ioannis Lianos and Damien Geradin (Cheltenham, UK and Northampton, MA, USA: Edward Elgar, 2013), 448.

${ }^{42}$ Damien Geradin and Nicolas Petit, "Judicial Review in European Union Competition Law: A Quantitative and Qualitative Assessment", Tilburg Law and Economics Center (TILEC) Law and Economics Discussion Paper No. 2011-008 and Tilburg Law School Legal Studies Research Paper No. 01/2011, (2010) https://orbi.ulg.ac.be/bitstream/2268/143359/1/GERADIN_PETIT_Judicial\%20 Review.pdf, 39.

${ }^{43}$ Damien Gerard, "Negotiated Remedies in the Modernisation Era: The Limits of Effectiveness", European Competition Law Annual 2013: Effective and Legitimate Enforcement of Competition Law, ed. Philip Lowe, Mel Marquis and Giorgio Monti (Oregon and Portland: Hart Publishing, 2016). Heike Schweizer, "Judicial Review in EU Competition Law", Handbook on European Competition Law: Enforcement and Procedure, ed. Ioannis Lianos and Damien Geradin (Cheltenham, UK and Northampton, MA, USA: Edward Elgar, 2013), 535.
} 
regarding due process. ${ }^{44}$ This discretion of the Commission is more troubling if one considers the pressure that the possibility of adoption of a formal infringement decision exerts on the undertakings, questioning the true voluntary nature of the commitments. ${ }^{45}$

In conclusion, the General Court's Morningstar judgment maintains ${ }^{46}$ the wide powers of the Commission in the context of Article 9 decisions and the high standard for third parties to challenge such decision. If, on the one hand, Alrosa widened the risk of undertakings being willing to accept more onerous remedies to avoid a fine, Morningstar, on the other, strengthens the possibilities of the Commission not taking into account the position of third parties. ${ }^{47}$

The confirmation of the wide discretion of the Commission and the limited scope of judicial review will keep making commitment decisions under Article 9 of Regulation 1/2003 a very attractive enforcement tool. However, issues such as regulatory agenda of the Commission, legitimacy in adopting commitment decisions in cases where the theory of harm is unclear and controversial, and proportionality will continue to be discussed.

\section{Bibliography}

Blanco, Luis Ortiz (ed.). EU Competition Procedure. $3^{\text {rd }}$ ed. Oxford: Oxford University Press, 2013.

Botteman, Yves, and Agapi Patsa. "Towards a More Sustainable Use of Commitment Decisions in Article 102 Cases", Journal of Antitrust Enforcement 1, 2 (2013): 347-374. Forrester, Ian. "Creating New Rules or Closing Easy Cases", in European Competition

Law Annual 2008, edited by Claus-Dieter Ehlermann and Mel Marquis. 407-452. Oxford: Hart Publishing, 2009.

Geradin, Damien, and Nicolas Petit. "Judicial Review in European Union Competition Law: A Quantitative and Qualitative Assessment", Tilburg Law and Economics

\footnotetext{
${ }^{44}$ Denis Waelbroeck, "Le Développement en Droit Européen de la Concurrence des Solutions Négociées (Engagements, Clémence, Non-Contestation des Faits et Transactions): Que Va-t-il Rester aux Juges?", GCLC Working Paper 01/08 (2008), https://coleurop.eu/research/global-competition-law-centre/working-papers, 3 .

${ }^{45}$ Ioannis Lianos, "Competition Law Remedies in Europe", Handbook on European Competition Law: Enforcement and Procedure, ed. Ioannis Lianos and Damien Geradin (Cheltenham, UK and Northampton, MA, USA: Edward Elgar), 2013, 450.

${ }^{46}$ One should not forget that in the Alrosa judgment of 2010 the European Court of Justice quashed the General Court's judgment of 11 July 2007, Alrosa v Commission, T-170/06, EU:T:2007:220, annulling the Commission decision mainly for not having respected the proportionality principle. ${ }^{47}$ Amaryllis Müller, "Morningstar v Commission - Setting the Bar High for Third Parties Challenging EU Commitment Decisions”, Competition Policy International (October 2016), 4.
} 
Center (TILEC) Law and Economics Discussion Paper No. 2011-008 and Tilburg Law School Legal Studies Research Paper No. 01/2011, (2010) https://orbi.ulg.ac.be/bitstream/2268/143359/1/GERADIN_PETIT_Judicial\%20Review.pdf.

Gerard, Damien. "Negotiated Remedies in the Modernisation Era: The Limits of Effectiveness", European Competition Law Annual 2013: Effective and Legitimate Enforcement of Competition Law, edited by Philip Lowe, Mel Marquis and Giorgio Monti. 139-184. Oregon and Portland: Hart Publishing, 2016.

Hoeg, Dorte. European Merger Remedies: Law and Policy. Oxford and Portland, Oregon: Hart Publishing, 2014.

Jenny, Frederic. "Worst Decision of the EU Court of Justice: The Alrosa Judgment in Context and the Future of Commitment Decisions", Fordham International Law Journal 38 (2015):701-770.

Jones, Alison, and Brenda Sufrin. EU Competition Law: Text, Cases and Materials. Oxford: Oxford University Press, 2016.

Lang, John Temple. "Commitment Decisions and Settlements with Antitrust Authorities and Private Parties under European Competition Law", in Annual Proceedings of the 2005 Fordham Corporate Law Institute, edited by Barry Hawk. 265-324. Huntington: Juris Publishing, 2006.

Lenaerts, Koen, Ignace Maselis, and Kathleen Gutman. EU Procedural Law. Oxford: Oxford University Press, 2014.

Lianos, Ioannis. "Competition Law remedies in Europe", Handbook on European Competition Law: Enforcement and Procedure, edited by Ioannis Lianos and Damien Geradin. 362-455. Cheltenham, UK and Northampton, MA, USA: Edward Elgar, 2013.

Marsden, Philip. “The Emperor's Clothes Laid Bare: Commitments Creating the Appearance of Law, While Denying Access to Law", CPI Antitrust Chronicle (October 2013) (1).

Nazzini, Renato. "Google and the (Ever-stretching) Boundaries of Article 102 TFEU”, Journal of European Competition Law \& Practice 6, 5 (2015): 301-314.

Paemen, Dieter, and Victoria S. Baltrusch. "Morningstar v. Commission: Raising the Threshold for Challenging Commission Commitments Decisions", Journal of European Competition Law \& Practice 8, 2 (2017): 99-101.

Schweitzer, Heike. "Commitment Decisions under Art. 9 of Regulation 1/2003: The Developing EC Practice and Case Law", EUI Working Papers LAW 2008/22 (2008) http://cadmus.eui.eu/bitstream/handle/1814/9449/LAW_2008_22. pdf? sequence $=1 \&$ is Allowed $=y$.

Schweizer, Heike. "Judicial Review in EU Competition Law”, Handbook on European Competition Law: Enforcement and Procedure, ed. Ioannis Lianos and Damien 
Geradin. 491-538. Cheltenham, UK and Northampton, MA, USA: Edward Elgar, 2013.

Vasconcelos, Rita Leandro. "Remedies and Article 102 TFEU: Recent Public Enforcement Experience", in Competition Law Challenges in the Next Decade, edited by Sofia Oliveira Pais. 179-193. Brussels: P.I.E. Peter Lang, 2016.

Waelbroeck, Denis. "Le développement en droit européen de la concurrence des solutions négociées (engagements, clémence, non-contestation des faits et transactions): que va-t-il rester aux juges?", GCLC Working Paper 01/08 (2008), https://coleurop. $\mathrm{eu} / \mathrm{research} /$ global-competition-law-centre/working-papers.

Whish, Richard, and David Bailey. Competition Law. $8^{\text {th }}$ ed. Oxford: Oxford University Press, 2015. 